\title{
LA NOVELA JARNESIANA Y SUS PERSONAJES DE FICCION
}

\author{
M. ${ }^{a}$ Pilar Martinez LATrE*
}

INTRODUCCION

Benjamín Jarnés** surge como escritor en una etapa histórica-literaria conflictiva y cambiante; presidida por la dictadura de Primo de Rivera. Es una etapa de vanguardias artísticas que tiene como signo la ruptura con el pasado y la adecuación a una nueva visión del cosmos.

Jarnés se erige en maestro de la generación Nova Novorum, cuyo credo estético se asienta en la renovación formal, en la adopción de un tono lírico y de nuevas perspectivas que se alejan de la observación de la realidad postulada por el realismo decimonónico, en un evidente deseo de renovación del género novelístico. Comparte esta generación actitu-

* Colegio Universitario de Logroño.

** Benjamín Jarnés (1888-1949). Nace en la Provincia de Zaragoza. Realiza estudios eclesiásticos, que abandona más tarde para ingresar en el ejército. Al sobrevenir la crisis de la causa republicana (1936), sale de su patria en condición de exiliado, eligiendo México como lugar de residencia. Regresa a España aquejado de una dolorosa enfermedad en 1948, enfermedad que le conduce a la muerte.

$\mathrm{Su}$ actividad literaria se inicia como colaborador en las principales revistas del momento: La Gaceta Literaria, La Hora de España, la Revista de Occidente, en donde ejerce la crítica asiduamente y se da a conocer como novelista con la obra El Profesor inútil (cuando contaba con treinta y ocho años de edad). Desde 1928 a 1936 se desarrolla su máxima actividad literaria, publicando una veintena de libros que lo sitúan en un primer plano crítico, ensayista, biográfo, pero de manera especial como novelista. Entre su repertorio variadísimo destaca: las biografías: Doble agonía de Bécquer, Espasa-Calpe, Madrid, 1936; La vida de San Alejo, Ed. Literaria, Madrid, 1934 etc... Los libros de ensayo: Cartas al Ebro (Biografía y crítica), La casa de España en México, México, 1940; Cita de ensueños (Figuras del Cinema), Eds. del Centro, Madrid, 1974 etc... Novelas: El convidado de papel, Espasa-Calpe, Madrid, 1935; Paula y Paulita, Revista de Occidente, Madrid, 1929; Locura y muerte de nadie, Oriente, Madrid, 1929. Teoría del zumbel, Espasa-Calpe, Madrid, 1936; Viviana y Merlin: Leyenda, Espasa-Calpe, Madrid, 1936; Escenas junto a la muerte. Espasa-Calpe, Madrid, 1931; Lo rojo y lo azul, Espasa-Calpe, Madrid, 1932; El Profesor inútil, Espasa-Calpe, Madrid, 1934.

Para conocer a Jarnés en todas sus facetas desde la crítica a la creativa, sin olvidar su posición teórica frente a la obra de arte, remito a mi tesis doctoral, presentada en Zaragoza, Noviembre de 1976 con el título: Aportación al estudio de la novela intelectual de Benjamín Jarnés (sin publicar). 
des intelectuales similares a las de otros escritores europeos del siglo $\mathrm{XX}$, propensos a la ideación, a la recreación del mito clásico, a la novela simbólica y a la novela de la novela, llegando a utilizar el mundo creado para proyectar su propia problemática, en un intento de análisis psicológico profundo, que revela el influjo de las corrientes psicoanalíticas de gran desarrollo en esta época.

Nuestro autor se revela como un escritor elitista, con un alto concepto de la obra de arte y de su creador. Posee una marcada influencia del pensamiento filosófico de Ortega y Gasset, pero se aleja de sus postulados deshumanizados en torno a la obra de arte, pues su teoría del arte por el arte no tiene sentido de evasión de la realidad, como algunos críticos han creído (Sobejano, Tuñón de Lara,** entre otros), sino el de una búsqueda más honda, más transcendental de la obra literaria, cuya función última está en la existencia libre de todo condicionamiento temporal.

\section{LOS PERSONAJES EN LA NOVELA JARNESIANA}

En el complejo microcosmos novelístico creado por Jarnés me voy a detener en sus personajes, obligada por las limitaciones espaciales impuestas en todo trabajo, limitación que viene compensada con creces por el papel primordial que los personajes ocupan en su mundo de ficción. A través de estos seres creados, el novelista pretende llegar al conocimiento íntegro del hombre, base de su creación artística.

No hace Jarnés una teoría del personaje literario, pero no cabe duda de que en su configuración refleja su concepto de la novela: la necesidad de dar entrada a la realidad inmediata, al inconsciente individual y al inconsciente colectivo. Le mueve, igualmente, el deseo de presentar al hombre íntegro: al hombre instintivo, sentimental e intelectual, o, lo que es lo mismo, en su propia concepción: al poeta, al filósofo y al científico.

Voy a centrar el estudio en dos planos: el de la caracterización o tipología de los personajes y el de su funcionalidad o participación en el acontecer y acción, pues sólo de este modo podremos captar su ego en su totalidad.

\section{A. PLANO DE LA CARACTERIZACION. ${ }^{1}$}

Los procedimientos a los que recurre Jarnés para afrontar la configuración de sus criaturas son muy diversos. La rigurosa sistematización

** Sobejano, Novela Española de nuestro tiempo. En busca del pueblo perdido. Madrid, Prensa Española, 1970, Introducción; Tuñón de Lara, Medio siglo de cultura española, Tecnos, Madrid, 1970, p. 256 y ss.

1 Me atengo a la terminología de René Jara y Fernando Moreno, Anatomía de la novela, Valparaiso, Chile, pp. 49 y ss. 


\section{La Novela Jarnesiana y sus personajes de ficcion}

de los mismos se corresponde con la descodificación que del mensaje novelístico hace el receptor: desde la más inmediata o directa: el nombre propio con que se presenta individualizado el personaje, a la más indirecta a través de los datos suministrados por el narrador ficto, por el propio discurso de los personajes etc., datos que se desprenden de la lectura de toda la obra.

Procedimientos utilizados en la caracterización:

A.1. Caracterización onomástica y sus variantes: Bíblica, literaria, mitológica, simbólica, y tipificadora; A-2. Caracterización emblemática; A.3. Caracterización fragmentaria y dispersa; A.4. Constantes configuradoras del héroe.

De cada uno de estos procedimientos caracterizadores seleccionaré algunos ejemplos de la variada galería de personajes que se mueven en el mundo creado por nuestro novelista; de este modo trataré de no caer en la prolijidad enumerativa que un análisis analítico puede conllevar.

\section{A.1. Denominacion Onomastica}

La caracterización se inicia por la denominación onomástica, la más inmediata para el lector (pero que exige de él una cierta formación cultural); denominación que posee para Jarnés una importante dimensión. Las palabras de Benjamín (personaje de ficción y autoproyección de Benjamín Jarnés) así lo confirman:

"(...) si fuésemos esclavos de nuestro nombre, realizadores de cuanto un nombre lleva encapsulado, iqué alegría!” (Libro de Esther, Introducción).

Utiliza, pues, este procedimiento caracterizador de manera especial en sus personajes secundarios y en algunos actantes básicos. Recurre, sobre todo, a la evocación de nombres sancionados por la Biblia, la Literatura y la Mitología, ${ }^{2}$ de forma que el personaje de ficción se impregna de sus atributos y cualidades y llega, en algunos momentos, a la fusión, de tal manera que el nombre de tradición bíblica, literaria o mitológica determina su comportamiento en la trama novelesca y le lleva a reproducir las mismas situaciones y conducta. Algunas veces, el giro de los acontecimientos por el que opta el personaje difiere del personaje sancionado que remeda. De este modo, Jarnés expresa sus preferencias y aversiones hacia obras y corrientes literarias, así como su ideología.

2 Entrambasaguas, "Benjamín Jarnés", en Las mejores novelas contemporáneas, Planeta, Barcelona, 1970, Vol. VII, p. 1.338, insiste en la recurrencia a la mitología en la novela jarnesiana para caracterizar a los personajes, y, así dice: "en los mitos, es decir, en los personajes metafísicos, vio la solución para dar a la mayoría de los suyos, con un nombre de aquéllos, un carácter definido hasta lo simbólico sin necesidad de describirlo o detallarlo realistamente; como una fórmula exacta de psicología que nadie puede confundir con otra ni con la variante realidad". 


\section{M. a Pilar Martinez Lat're}

En la denominación de los personajes, Jarnés sigue una tradición antiquísima, que se registra en la Biblia, ${ }^{3}$ según la cual, el nombre, lejos de ser una designación convencional, expresa el papel de un ser en el universo, la actividad o el destino del que lo lleva. Las afinidades del personaje con la denominación bíblica que porta, son evidentes, ya que al igual que el texto sagrado, en el que cada ser lleva el nombre que corresponde a su papel, en algunos personajes jarnesianos se producirá el cambio de nombre cuando en él se evidencie un cambio de actitud vital. Matilde será Rebeca hasta que el amante conozca su entorno familiar (Locura y muerte de nadie), Guillermina se convertirá en Araceli, cuando pase de ser la convencional burgesa a la prostituta resentida ( $L o$ Rojo y lo $A z u l$ ), Saulo intentará ser Pablo sin conseguirlo (Teoría del Zumbel).

\section{A.1.1. Denominacion Biblica}

Entre los personajes caracterizados por nombres de procedencia bíblica destacan: Saulo, Rebeca y Salomé.

La caracterización onomástica del protagonista de Teoría del Zumbel con el nombre de Saulo es una clara demostración de la recurrencia al apóstol San Pablo en su proceso vital (especialmente, en su primera etapa). Las situaciones vividas por este personaje ficto "Saulo" son paralelas a las del hombre histórico. Ambos nacen de familia ilustre y poderosa, con un temperamento impulsivo y apasionado. Las diferencias se basan en la diversa situación socio-histórica. El apóstol destacará por su ensañamiento en la persecución de los cristianos, mientras que el actante básico se mostrará escéptico en sus creencias religiosas y volcará sus impulsos desenfrenados en una vida orgiástica en persecución de todo lo establecido. La vida del apóstol que sigue un camino torcido, equivocado, se ve rectificada por la llamada divina convirtiéndose al cristianismo. Del mismo modo, el personaje jarnesiano, conmovido por la presencia de una mujer llamada Blanca, decide rectificar su vida:

"Blanca (...), deja caer una furtiva mirada y su Camino de Salvación (...). Inescrutables designios. ¡De aquí, precisamente de aquí, de esta doble caída, arranca el brote novelesco! Un joven se aproxima a recoger un librito (...). - ¿Es una broma del cielo? Porque soy un descarriado, guapa" (Teoría del Zumbel, p. 41).

El paralelismo con el hombre bíblico tiene nuevas implicaciones: ambos sufrirán una conmoción. El apóstol caerá del caballo, y el Saulo del siglo XX caerá de su coche en un aparatoso accidente. Pero la caída liberadora del apóstol, al encontrarse con Dios, se resolverá negativa-

3 Sobre el nombre y su significado en la Biblia, vid. Léo-Dufour, Vocabulario de Teología Bíblica, Barcelona, Herder, 1966. 


\section{La Novela Jarnesiana y sus personajes de ficcion}

mente en el héroe jarnesiano, apresado por las garras fatídicas de la muerte que le impiden realizar la conversión hacia un hombre nuevo.

Entre los personajes femeninos denominados con nombres bíblicos, encontramos a Rebeca. Rebeca aparece como denominación de dos personajes femeninos en dos importantes novelas: Locura y muerte de nadie, y en la segunda edición de $E l$ profesor inútil (en el episodio titulado Trótula).

En la novela Locura y muerte de nadie, es Matilde la que recibe el nombre de Rebeca, únicamente en los tres primeros capítulos, hasta que el amante conoce su entorno familiar. Es entonces cuando su nombre se despoja de la evocación bíblica. Su primera aparición en el relato evoca fugazmente a Rebeca en su primer encuentro con el siervo de Abrahán. La Rebeca bíblica cargada de connotaciones simbólicas, ${ }^{4}$ impregna de ellas al personaje femenino de Jarnés. Pero, cuando la mujer amada es descubierta en su sórdido entorno familiar, tiene que despojarse del nombre que la idealizaba. El idealismo de Jarnés se manifiesta en este detalle significativo, en total coherencia con sus criterios: cree que para gozar plenamente de la mujer no hay que incidir en su historia personal, en su entorno y circunstancias, pues éstos la despojan de su perfección:

\footnotetext{
"Tal mujer, que en el primer encuentro aparecía desnuda, en total desarraigo del mundo, como una fruta madura que aguarda una mano, ya en el segundo se nos va vistiendo de su oscura historia racial, de su pobre historia doméstica" (El profesor inútil, p. 194).
}

El segundo personaje, denominado con el nombre de Rebeca, aparece en el Profesor inútil, y evoca a la mujer bíblica en su aparición con el cántaro junto a la fuente, una fuente que, en el relato de Jarnés, se convierte en la fuente de la hechicera Trótula.

La imagen de Rebeca ejerce sobre Jarnés un especial atractivo. Desde su primera novela, reconocida como tal por la crítica, Rebeca es una de las figuras que puebla los ensueños y las evasiones de Julio:

"Siempre una mujer filtrándose por lo más tupido de la mística, alevosamente, con el aire cándido de Rebeca, ingenua moza de cántaro que viene a apagar nuestra sed" (El convidado de papel, p. 100).

El personaje de Salomé que aparece en el mundo onírico de Jarnés (en la novela Teoría del Zumbel) tiene sus raíces más remotas en la $\mathrm{Bi}$ blia; es la bailarina que exigió al rey la cabeza del Bautista, que lo sedujo con su baile sensual de los siete velos, y que ha sido siempre por la tradición literaria relacionada con la tentación y la lujuria. Cargada de connotaciones procedentes de la iconografía modernista, que tuvo por este personaje una especial predilección, es la mujer fatal que desencadena la pasión y la muerte. Aparece en los momentos de inconsciencia

4 C. Falconi. Cfr. Dic. Literario, Gonzalo Porto-Bompiani, op. cit., p. 797. 


\title{
M. ${ }^{a}$ Pilar Martinez Latre
}

de Saulo, todavía sin recuperarse de su "shock" al producirse un accidente de coche, confundiéndola con la luna (esta imagen de Salomé, fundida con la luna, símbolo de la muerte, tiene en los poetas de la generación del 27 un atractivo especial):

\begin{abstract}
"Porque la luna acude -como siempre- a pedir su trino de violín en esta Escena junto al arroyo. Viene amarilla, color de hueso, neurótica, luna de pastoral (...) trae su cara de Salomé. Es la misma Salomé que acude -como todas las noches- a abrazar a Saulo, antes de desnudarse, para pedir la cabeza de un espectador de la primera fila de butacas" (Teoría del zumbel, p. 171).
\end{abstract}

\section{A.1.2. Denominacion Literaria}

En las denominaciones literarias nos detendremos en: Julio, Adolfo y Elvira. Entre esta serie de nombres, cargados de connotaciones, destaca Julio por su reiterada aparición entre los héroes jarnesianos. Me parece necesario insistir en la importancia que este personaje tiene en Jarnés. La admiración que en todo momento manifiesta por la obra de Stendhal hace probable pensar que este actante básico esté conformado análogamente, en cuanto a la etimología del nombre y psíquicamente en cuanto a su comportamiento, con Julien Sorel, héroe de Le Rouge et le Noir.

El personaje y su nombre pueden considerarse como un leit-motiv que perfila el carácter y pone de relieve, una vez más, las afinidades entre el personaje de Stendhal y el de Jarnés. Su nombre es evocado constantemente en el mundo representado.

En la novela $E l$ convidado de papel, Julio es introducido por Adolfo, en la lectura del libro Le Rouge et le Noir. La breve presentación que Adolfo hace de él atrae a Julio, que confiesa con entusiasmo: "será el autor buen amigo mío" (p. 166).

Parece como si su lectura hubiera iluminado el camino de su vida, reflejada a su vez en sus personajes.

En la segunda edición de El Profesor inútil, el personaje protagonista evoca a Julien Sorel y a su comportamiento como "dómine", comportamiento que trata de imitar:

"¿No había tenido Julián Sorel la preocupación de preguntar, antes de actuar como dómine, con quien había de comer? ¿Por qué no pregunté por qué puerta había yo de entrar?" (El profesor inútil, p. 13).

En la novela Paula y Paulita, Julio muestra su admiración por Stendhal, en un superficial ejercicio de crítica literaria; los escritores favoritos reciben de su proveedor un enorme fajo de cuartillas para que sigan escribiendo:

"Gozamos de pequeñas venganzas, de favoritismos, de deliciosas intimidades. (...) a Góngora le tenemos reservado un vagón de cuartillas. y otro a Stendhal" (Paula y Paulita, pp. 107-108. El subrayado es mío). 
Finalmente, la novela Lo Rojo y lo Azul nace como homenaje explícito de Jarnés, manifestado en su introducción de "El inimitable Julien Sorel". El paralelismo y afinidades se inician con el título de la novela, y continúan en algunos rasgos de la personalidad del joven seminarista. Sorel abandonará sus estudios e iniciará una sorda lucha para situarse en la sociedad; mostrará una compleja personalidad a través del sutil proceso sentimental en el que vive inmerso. Por eso, su espíritu sensible y romántico tiene para Jarnés un atractivo especial, pues, en cierto modo, se siente proyectado e identificado con él. Y, por eso, dentro del mundo representado se erige en un personaje simbólico, contrafigura del mismo Jarnés. Aparece dando nombre al protagonista de varias novelas: $E l$ convidado de papel, Lo rojo y lo azul y Paula y Paulita. Probablemente la recurrencia a este nombre se deba a la proyección autobiográfica de su autor, como he señalado ya. Así, encontramos al héroe de El convidado de papel narrando su infancia y adolescencia en el seminario, e igualmente, al héroe de Lo rojo y lo azul conectado con el personaje de $E l$ convidado de papel, joven recién salido del seminario que se va a enfrentar con el servicio militar, "tránsfuga de un taller sacerdotal". Este segundo Julio podría representar el proceso de anagnórisis en que el héroe trata de encontrarse consigo mismo, iniciando una nueva etapa, lejos de la represiva vida del seminario. El narrador establece constantes conexiones entre ambos:

"Julio, en sus primeros años de adolescencia, había recorrido la ciudad convertido en salvaje, cerrados los ojos a cualquier alta contemplación" (Lo rojo y lo azul, p. 13).

El mismo personaje de Lo rojo y lo azul, al ser preguntado por su pasado, evocará los momentos vividos en el seminario por el Julio de El convidado de papel y se siente como un novicio ante la vida real, pues anteriormente había permanecido inmerso en un mundo de evasión, creado por él mismo para soportar la tediosa vida en el seminario:

"Soy, pues, un hombre que chamarilea en tropos, un atolondrado viajante en nubes" (Ibid., p. 16).

Las afinidades son menos claras en el Julio de Paula y Paulita.

En cuanto a Adolfo, nos encontramos de nuevo un héroe romántico, el "Adolphe" de B. Constant (Le journal intime), para denominar a otro joven seminarista, personaje de El convidado de papel. El paralelo entre los dos Adolfos es evidente. El héroe de Constant se plantea el problema de la incapacidad de amar, unido a una invencible necesidad de amor. ${ }^{5}$ También el personaje de Jarnés vive en un maniqueísmo que

${ }^{5}$ El mismo Benjamín Constant explica el propósito que le llevó al crear este personaje:

"He querido pintar en Adolphe una de las principales enfermedades morales de nuestro siglo, esa fatiga, esa incertidumbre, esa carencia de fuerzas, ese análisis perpetuo que sitúa al lado de todos los sentimientos, una segunda intención que así los corrompe desde su nacimiento" (Pyre, Qué es verdaderamente el romanticismo, Madrid, Doncel, 1972, p. 106). 


\section{M. a Pilar Martinez Latre}

le oprime y le desazona: el amor religioso en lucha constante con su necesidad de amor humano; se siente culpable ante la pasión amorosa que le devora y que él mismo juzga como debilidad y pecado apartándole del camino de perfección al que aspira. Adolfo se alza como caricatura del héroe romántico del que Jarnés se muestra acérrimo enemigo. Sus juicios son duros e incisivos ante la postura del personaje que guarda en secreto su amor y, así, Julio piensa de él:

“Acaso presiente que, al arrancársele todo el secreto, se le quedará vacío el corazón, su pobre corazón romántico capaz de ser teatro de todas las catástrofes" (p. 196).

Elvira es el personaje que preside un episodio de la novela Escenas junto a la muerte. Posee una denominación de fuertes connotaciones que determinan su psicología y el comportamiento del personaje romántico; de esa Elvira de Pastrana que emerge de la poesía de Espronceda en su obra El estudiante de Salamanca. Es el soplo que inspira a Jarnés, la muchacha definida por F. Carlesi ${ }^{6}$ como

"Más bella y más pura que el azul del cielo, con los ojos lánguidos, dulces y serenos de muchacha desgraciada e inocente (...) embriagada de amor, está extasiada ante su amante D. Félix de Montemar, Elvira no tiene otra luz que el joven e impío libertino".

De esta misma forma la describe el opositor $n .^{\circ} 7$, que vive un amor contemplativo, casi hipnótico, proyectado en esta deliciosa mujer, dotada de armonía y perfección suma

"E1 amor no fue en ella anárquico, ni siquiera panteísta; fue arquitecto" (Escenas junto a la muerte, p. 92).

Pero el marco connotador de este personaje romántico tiene resonancias más amplias. Como las aguas del estanque se ponen en moviImiento creando círculos concéntricos en torno a la piedra que las ha despertado de sus tranquilos sueños, así Jarnés describe sus círculos en torno a la imagen de Elvira, de la que el mismo personaje masculino se siente impregnado: el héroe, personaje protagonista y narrador de la ficción, el anónimo opositor $\mathrm{n} \circ^{\circ} 7$, experimenta los mismos sufrimientos amorosos que sintió Elvira de Pastrana. Borrados pasado y futuro, vivirá el instante presente con la obsesión de un demente; la mujer se apodera de todo su ser. Es similar actitud a la que encontramos en la heroina de Espronceda que vive envuelta en el ensueño y llega a perder la razón.

Sin embargo, el héroe jarnesiano romperá estos círculos obsesivos al salir del delirio y recobrar la razón.

Un caso especial lo constituyen los personajes de raigambre me-

- F. Carlesi, Cf. Diccionario Literatura, op. cit., vol XI, p. 310). 


\section{La Novela Jarnesiana y sus personajes de ficcion}

dieval Viviana, Merlín y Trótula, que caracterizan a criaturas jarnesianas dotadas de valor simbólico, que, en el caso de Viviana, se amplifica al sintetizar también valores míticos.

Viviana, personaje de Viviana y Merlín, posee una larga tradición,? especialmente en los relatos artúricos de los trovadores anglo-normandos. Viviana y Merlín nacen como contrarréplica explícita de la famosa obra del poeta inglés Alfred Tenmynson, Los Idilios del rey. La Viviana inglesa representa la lujuria, la astucia y la falsedad. La Viviana de Jarnés está rodeada de atributos y cualidades semidivinos. Es la fuerza de la naturaleza:

"Nací con el primer brote de una primavera -nadie sabe cuál- porque todas son una y la misma" (Viviana y Merlín, p. 78).

Ninfa, que encarna la belleza natural, que posee todos los conocimientos sobre la naturaleza física y humana. Está dotada de gracia y armonía que le permiten conquistar el cerebro de la corte: Merlín, el encantador. Viviana se erige como armonizadora de esta corte medieval, pues

“(..) intentó convertirla en una estructura armoniosa, hacerla vivir, crecer, desmoronarse a su tiempo" (Ibíd., p. 153).

Para Jarnés, Viviana simboliza, a lo largo de su mundo novelístico, el ingenio, y, especialmente, la mujer dotada de todas las más hermosas cualidades, capaz de subyugar al hombre razonador (el científico Merlín), al hombre sentimental (los caballeros) y al hombre instintivo (la servidumbre y soldados del castillo), pero Viviana será mucho más en la visión de Jarnés: es la gracia, la picardía, que triunfa en la rígida sociedad medieval y siempre. Si Eufrosina era la Gracia, Viviana es la síntesis de las tres Gracias.

\section{A.1.3. Denominacion Mitologica}

La denominación mitológica tiene para Jarnés un atractivo especial. La mujer aparece frecuentemente caracterizada con bellos y evocadores nombres de divinidades femeninas de la mitología clásica: Juno, Afrodita, Minerva, Cloe, Circe, Ceres, Cibeles, Dánae, etc. A este sugestivo elenco de bellezas mitológicas se unen, en menor proporción, las divinidades masculinas: Apolo, Ariel, Cyparisos, Hyacinthos, Fauno, etc., para denominar algunos de sus personajes masculinos.

7 Viviana y Merlín protagonizan la novela alegórica del mismo nombre. Sobre la personalidad literaria de Viviana y Merlín es de gran interés el estudio de Luis Bonilla en Los mitos de la humanidad, Madrid, Prensa Española, 1971, pp. 205-221. 


\section{M. ${ }^{a}$ Pilar Martinez Latre}

Le mueve a Jarnés, en este bautizo de sus personajes femeninos, una admiración constante por la mujer, a la que trata de ascender desde el plano humano al semidivino, porque la mitología permanece viva en él:

"Los dioses vuelven siempre a nosotros (...). Hoy ya constituyen un museo vivo, un museo en medio de la calle (...). Renació el arte porque los dioses renacieron, renacerá cuantas veces el poeta retorne a las auténticas fuerzas vivas del universo".

Según Jarnés, el hombre repite constantemente, a lo largo de su devenir histórico, comportamientos de nuestros antepasados mitológicos, latentes en el subconsciente colectivo. Por eso, estas denominaciones aparecen en un juego dicotómico: el apelativo corriente junto al nombre sancionado. Así, Cecilia será Circe; Susana, Juno; Isabel, Afrodita; etc.; pues sólo fugazmente aparecerán investidas de estas aptitudes míticas, constituyendo, unas veces, un rasgo de carácter, viviendo, otras, sus mismas circunstancias, $o$, simplemente, reviviendo una atractiva imagen mítica, de gran belleza plástica, que nace en la mente del artista como ocurre con Dánae al ser contemplada bajo los efectos de una luz peculiar. En este caso, es la visión pictórica la que seduce a Jarnés, probablemente las doradas pinceladas de un Tiziano.

Dánae es una denominación mitológica atribuida a diferentes personajes femeninos del mundo novelístico jarnesiano. Su primera aparición la encontramos en El convidado de papel.

Eulalia, la joven profesora que hechizará por su belleza, juventud y desenvoltura al pueblo, es presentada como una Dánae en una visión de gran belleza plástica. La historia mítica poco importa en este caso a Jarnés. Solamente se siente sugestionado por el valor pictórico del mito; un cuerpo femenino que reposa desnudo y recibe el regalo del oro sobre la belleza de su carne. El oro ya no es Júpiter, sino el sol, soberano del mundo, sensualmente prendado de la morbidez de la hembra hermosa:

"La ventana está abierta, y la maestra, totalmente desnuda, recibe de lleno en su carne la frenética embestida del sol. Resbala la luz por su vientre, se le anilla en el regazo, gime prisionera entre los muslos finos, estremecidos" (El convidado de papel, p. 32).

Se palpa en la descripción la delectación sensual en la que se recrea Jarnés con frecuencia. ${ }^{9}$ Pero la visión mítica, ahora bajo el prisma de la realidad cotidiana, queda trivializada:

8 Romance, "Museo en la calle", México, n. ${ }^{\circ}$ XXIV, p. 18.

9 La funcionalidad del mito en relación con la trama novelesca no tiene aquí importancia. Son las bellas connotaciones pictóricas de la historia mítica las que conmueven a Jarnés, evocando, probablemente, el célebre cuadro de Ticiano, desnudo de prodigiosas formas nada lúbricas, en donde se destaca la presencia de un Júpiter que, enamorado de la diosa, irrumpe en la torre, donde estaba prisionera, convertido en lluvia de oro. 
"Por prescripción facultativa, Eulalia se convierte cada mañana en una sumisa Dánae" (Ibíd., p. 32).

Jarnés juega con el mito y lo humaniza. El paisaje se enriquece con nuevas connotaciones. La mujer —Dánae-, una bella carne de mujer desnuda, recibe como regalo la lluvia de oro, que es el sol, y es la luz y la vida superior: la glorificación. Y, a la vez, por la simbología del oro ${ }^{10}$ su cuerpo se convierte en un tesoro de difícil acceso: "Julio nunca había tocado el oro" (dice el narrador, refiriéndose al elemento real, material), y la primera vez que pone sus manos sobre el cuerpo desnudo de esta mujer

“...como un príncipe que acaba de descubrir, encerrados bajo siete llaves, los tesoros ocultos de un reino, hunde sus manos en la crispada hondura y comienza a remover el oro puro, (...) acumulado en ella por el sol. Sus manos apenas forjadas, que ya se adiestran en modelar la materia viva. Preciosas manos de infante que han tocado el oro de los dioses llovido sobre la epidermis fugitiva de las rosas humanas" (Ibíd., pp. 33-34; el subrayado es mío).

Está divinizando un cuerpo de mujer. No diviniza a la mujer, sino a su carne desnuda, en ese momento pasajero (la juventud y la belleza). Fijémonos que habla de epidermis fugitiva y de rosas humanas, con toda la nostálgica evocación de transitoriedad que lleva consigo la hermosura de la rosa. Para Jarnés, Eulalia es Dánae:

"Heroína de mitos infantiles, de cuentos románticos, alma inflamable que se consume de amor" (Ibíd., p. 217).

Que despierta al niño a la sensualidad. Y desde este contacto con la mujer dejará de serlo, para iniciarse, en una dulce ascensión, como hombre apasionado, rendido amante de la hembra. La mujer se erige en la "labradora del sentimiento", como había anunciado Ortega en la cita que inicia la novela. Es la maestra de la vida que no enseña el frío y simple texto del libro infantil, el Juanito. Bajo su contacto, el niño

"siente una inquietud de cuyo origen nunca le habló el 'Juanito" (Ibíd., p. 34).

Eulalia, la divina Dánae, vuelve a seducir a un joven seminarista, Adolfo, presentándose de nuevo ante los ojos del inexperto adolescente como la mujer de espléndida belleza, en medio de una naturaleza sensual,

${ }^{10}$ El oro encierra un polisémico valor simbólico. Cirlot señala (Diccionario de símbolos, op. cit., p. 356) en primer lugar la visión del oro como imagen de luz y por consecuencia de inteligencia; en segundo lugar, el valor de todo lo superior, la glorificación; por último, el oro como valor esencial del simbolismo del tesoro escondido o difícil de encontrar, imagen de los bienes espirituales y de la iluminación superior. 
en donde la plasticidad y sensorialismo atraen y arroban al joven Adolfo y al más desapasionado lector:

"El sol coronaba la fiesta. Penetraba a torrentes por la ventana que daba al cuarto, arrancaba de las ramas jocundas melodías verdes. El aire llegaba hasta nosotros jugueteando, meciendo en sus ondas una turbulenta sinfonía de perfumes. Todos los sentidos pudieron celebrar alli su fiesta, ante una carne trémula, electrizada. Como Dánae, recibí, plenamente ofrecida, el regalo de un dios. De un dios arrollador y tímido, potente y medroso." (Ibid., p. 248).

En este constante jugueteo, en el que se mueven algunos personajes de Jarnés, entre la realidad cotidiana y la realidad mitológica, Eulalia es una maestra de inigualable belleza. Cuando la realidad que la rodea le es hostil (como ocurre en su visita al seminario ante las miradas inquisidoras, cargadas de juicios condenatorios de los familiares de los seminaristas), se transforma en una altanera Dánae:

"Eulalia proclama su alto señorío. De una sacudida se desprende de todas sus cautelas $y$, desnuda de su pudor, imprime a sus gestos una ardiente vibración provocativa. Sobre ella desciende una lluvia de lentejuelas de oro" (Ibid., p. 223).

El recinto entero se transforma para albergar a la diosa mitológica. En contraste con esta bella Dánae que nos evocan los pinceles de los maestros italianos, se erige la imagen de otra Dánae, personaje innominado y anecdótico de la novela Locura y muerte de nadie, que se presenta en la fría y materializada atmósfera de un Banco, para recibir el fruto divino, el trigo dorado (dios de los cereales), en una bella imaginería alegórica, como homenaje a la belleza de la naturaleza y de la mujer:

“(...) una espléndida Dánae, que, con un cheque en la mano, va a cobrarse alguna transitoria cesión de su belleza. La lluvia de oro desciende ahora al número 344 , corre a lo largo de sus opulentos flancos...

Dánae abate, al fin, la cabeza. La sumerge en el otro mundo, en el mundo de los números y de las máquinas" (Locura y muerte de nadie, p. 1.398).

La visión de la diosa se trivializa y se carga de matiz irónico, revelando, una vez más, su desprecio por el mundo bursátil.

Finalmente, en fugaz transformación, se contempla de nuevo a Dánae en la joven Paulita, personaje de la novela Paula y Paulita, cuando recibe la lluvia caliente de las aguas termales:

"Paulita (...), trémula bajo la lluvia ardiente, tan cercana al temblor de una Dánae bajo la ráfaga de oro derretido" (Paula y Paulita, p. 59).

La belleza plástica del mito ha hechizado al novelista, que lo eleva a símbolo de la sensualidad. 
Podrían mostrarse otros ejemplos de denominación mítica, pero la belleza del presentado invita a callarlos.

\section{A.1.4. Denominacion Simbolica}

Las denominaciones onomásticas de carácter simbólico recogen toda una escala de connotaciones que configuran a determinados personajes. Estas denominaciones van desde un aspecto sensorial (Blanca, Rubí) hasta la confluencia de aspectos más profundos: el espiritual y la actitud vital (Blanca, Mister Broock). En estos dos personajes el nombre incide en la perspectiva de la narración. Blanca sigue siendo Blanca porque el autor trata de demostrar su actitud distante e inhibidora en el desarrollo de los hechos novelísticos. Mr. Brook es la perspectiva anglosajona de hechos españoles.

Algunos personajes aparecen desprovistos de nombre propio; todo ello obedece a la reacción de Jarnés ante los postulados realistas. Los nombres genéricos y abstractos se cargan de valor simbólico: la condición del hombre-masa que unas veces se somete y, otras, se rebela ante su pequeñez. Así se produce con los protagonistas de las novelas Paula y Paulita, Escenas Junto a la muerte y El profesor nútil, que se denominan, respectivamente, número 479 , el opositor $n .^{\circ} 7$ y el profesor inútil.

\section{A.1.5. LA DENOMINACION TIPIFICADORA}

La denominación tipificada corresponde a los personajes incidentales o episódicos. Al ser personajes-tipo, sin apenas rasgos que los caractericen, no necesitan de nombres propios; por eso, aparecen denominados con el nombre del sector social o rol que desempeñan en la ficción: el cantarero, el guía, el prestidigitador...

\section{A.2. LA CARACTERIZACION EMBLEMATICA}

La caracterización emblemática recae en los personajes secundarios y anecdóticos, pues, en general, son personajes planos que apenas experimentan evolución alguna a lo largo de la ficción novelesca, presentándose simplemente con un rasgo dominante, cualidad o defecto, que determina o pone de relieve su temperamento y qu puede incluso condicionar su vida, como ocurre con Guillermina, en Lo rojo y lo azul, o con Juan Sánchez, en Locura y muerte de nadie, o con Paula, en Paula y Paulita.

A través de la caracterización emblemática, Jarnés plasma su concepción e ideología sobre la mujer, el clero, las profesiones liberales. Mediante este procedimiento, incide en la tesis novelística y la subraya. 
La preocupación de la mujer por la belleza determina su actitud ante la vida. Este comportamiento puede ser consciente (Paula, en Paula y Paulita, o inconsciente (Guillermina, en Lo rojo y lo azul; Rebeca, en El profesor inútil; Matilde, en Locura y muerte de nadie. Paula trata en todo momento de borrar las huellas del tiempo en su rostro y en su cuerpo. Esta preocupación de Paula por su belleza se convierte en un rasgo emblemático. Frente a ella, la belleza fresca de la juventud de Paulita contrasta con la dulce madurez de su madre. La actitud despreocupada, cuando no agresiva, responde a la seguridad en su propia belleza y juventud. Y, sin embargo, Paula desplaza a su hija, se alza en símbolo de la inalterabilidad del espíritu frente a la fragilidad de la carne, ya que, en definitiva, para Jarnés, la belleza del espíritu, como pensaba Platón, ${ }^{11}$ es superior a la belleza del cuerpo, y sólo quien contempla en la belleza la medida eterna puede gozar de ella plenamnte.

La imperfección física, no suplida por la belleza y pureza del espíritu, conduce a Guillermina a resarcirse inconscientemente de su fracaso mediante su adscripción a movimientos revolucionarios. A través de esta actitud, Jarnés reafirma su tesis de la mixtificación de los compromisos políticos.

Otras veces, la mujer, al reconocer su propia belleza y ser contemplada por el amante, adopta una actitud de pudor; actitud compartida por Rebeca (El profesor inutil) y por Matilde (Locura y muerte de nadie), en un mismo gesto instintivo e inconsciente. Jarnés ve en esta actitud, potenciadora de la sensualidad, "una deliciosa manera de ser casta".

Frente a esta admiración jarnesiana, Araceli (El convidado de papel), la "venus mercantil" que comercia con su belleza y tasa el tiempo del cliente, impide el goce pleno que exige la contemplación morosa para la aprehensión total de la belleza. Por su mercantilización, es la mujer que simboliza la belleza degradada, tan lejos del mundo de valores jarnesianos.

También es una degradación femenina la sumisión conformista de Matilde (Lo rojo y lo azul), mujer sin voluntad que se erige en representante de la humanidad oprimida. Esta opresión es clara represión en Julia (Teoría del zumbel), mujer que como Matilde, carece de atractivo físico. La ausencia de belleza, según Jarnés, comporta inexorablemente el fracaso femenino.

El medio opresor en el que se mueven estas dos mujeres es superado por la madre de Patricio (Locura y muerte de nadie), a través de su bondad, su espíritu maternal y el amor que pone en ese entorno rural, que, por el contrario, oprime al hijo. Jarnés valora en esta mujer la entrega sin reservas, la dulzura y la inteligencia, sus rasgos emblemáticos más sobresalientes.

Es evidente que la belleza de la mujer es uno de los valores estéticos más apreciados por nuestro autor y sus héroes. Si la mujer en la cosmovisión jarnesiana es una síntesis de naturaleza y arte, una diosa,

11 Edgard de Bruyne, Historia de la estética, capítulo "Lo bello platónico", Madrid, B.A.C., 1963 , pp. 47 a 64. 
aquéllas que no reunen este canon de belleza o que lo han prostituído se convierten en personajes tipo (la solterona resentida, la esclava de una sociedad capitalista, la insatisfecha revolucionaria, la prostituta...), incapaces de despertar el amor o el deseo de los actantes básicos.

Otros rasgos emblemáticos caracterizan a personajes que viven inmersos en determinadas profesiones o estados. De nuevo, estos rasgos apoyan y subrayan la ideología de Jarnés ante determinadas formas de vida. De ellas, la más ampliamente tratada es la del clero, por ser éste uno de los estamentos que Jarnés conoció más de cerca. Nuestro autor proyecta en la caracterización de estos personajes su desacuerdo con la vida religiosa que le fue impuesta para solucionar los problemas económicos familiares y vuelca también su ideología: su defensa de la libertad en oposición rotunda a la rígida disciplina del seminario. Profesores y alumnos se presentan dentro de su mundo ficto con una personalidad ramplona, identificados por sus aficiones, debilidades, que se convierten en tics o rasgos caricaturescos.

Los seminaristas de Jarnés son seres anodinos que carecen de problemas profundos y se satisfacen con nimiedades que los caracterizan emblemáticamente: la retórica polémica de periodista decimonónico, la insensibilidad musical, la obsesión erótica del conquistador frustrado. Los sacerdotes que rigen el seminario están caracterizados por su torpe$z a$, su inflexibilidad, su ampulosidad erudita y su falta de inserción en el mundo, su misoginia o la exacerbada pasión erótica estimulada por un celibato impuesto. Sólo el bonachón don Mariano se salva de ese menosprecio con el que Jarnés los juzga. De nuevo, la bondad exculpa a un personaje sometido a los placeres de la mesa con los que trata de paliar su escasa formación teológica.

Todos estos personajes que pueblan El convidado de papel están cacaracterizados también por sus rasgos físicos y por el aspecto exterior: la obesidad, la delgadez, la estatura inarmónica, el aspecto desaliñado, el sensual y el lujurioso.

Estas figuras están vistas desde una perspectiva que trata de satirizar un mundo de vida religiosa que Jarnés no aceptó nunca.

Uno de los rasgos que Jarnés utiliza con predilección para caracterizar a los personajes es el timbre de la voz, que refleja el espíritu de quien la emite: la voz de "dulzura maternal" de la madre de Patricio (Locura y muerte de nadie); la agresiva de Paulita (Paula y Paulita); la "pastosa y sin timbre" "voz en serie" del marqués de Cosuenda (Escenas junto a la muerte); la "diabólica y seductora" del cabo Ramírez (Lo rojo y lo azul); la "opaca y vinosa" de Bruno, "sin centelleo alguno del espíritu" (El convidado de papel).

Dentro de este procedimiento caracterizador hay otros rasgos característicos que vienen a configurar a los personajes, pero son los arriba transcritos los más reiterados en la ficción. 


\section{A.3. LA DENOMINACION FRAGMENTARIA Y DISPERSA}

La denominación fragmentaria y dispersa se presenta en los actantes básicos, personajes de carácter esférico, ${ }^{12}$ que experimentan una evolución a lo largo de la ficción, Jarnés quiere llegar a través de ellos al conocimiento íntegro del hombre como compendio de tres realidades: inmediata, intuitiva e inconsciente; en definitiva, al conocimiento de sí mismo, al fusionarse su propia existencia con sus personajes actantes.

En esta caracterización participa el narrador omnisciente que analiza el comportamiento y describe las cualidades y defectos del personaje, haciendo gala de su situación privilegiada. Se deja oir su voz creadora, inmersa en la ficción o distanciada de ella en los enclaves no narrativos, en los que suele haber un frío análisis del personaje. Otras veces, la caracterización está en manos del propio actante, a través del monólogo dirigido e indirecto, o de la carta, procedimientos que permiten conocer la parte más recóndita de su personalidad, su realidad inconsciente. Finalmente, esta caracterización se realiza también a través del diálogo entre el actante y otros personajes, o entre otros personajes, que exponen sus opiniones o emiten su juicio sobre el héroe. De este modo, se pone de manifiesto la humanidad de unos personajes que, como actantes básicos, no están hechos de una sola pieza.

En los personajes secundarios la caracterización indirecta es menos importante, y sólo los personajes coprotagonistas aparecen caracterizados mediante los procedimientos analizados anteriormente. De este modo, se pone de relieve, como comprobamos en la funcionalidad, la importancia del héroe, a cuyo proceso vital se circunscribe la ficción, siendo los demás personajes del mundo ficto, por lo general, personajes antitéticos o contrastantes, o personajes miméticos del actante básico, con una personalidad menos compleja y un comportamiento que apenas experimenta modificaciones. Entre estos personajes se hallan Adolfo (El convidado de papel) y Arturo (Lo rojo y lo azul).

Pero en estos procedimientos, en los que confluyen el héroe, el narrador-omnisciente y los otros personajes, como vehículo de caracterización, hay diversos matices de técnica y de perspectiva; de entre todos ellos presentaré algunos ejemplos.

Desde las primeras novelas, es frecuente en el mundo jarnesiano la presencia del narrador-omnisciente, a través del cual se dan a conocer algunos rasgos relevantes del carácter del personaje y su comportamiento y actuación en algunas etapas de su vida. Es un procedimiento que Jarnés seguirá utilizando posteriormente.

En una de sus primeras novelas (El convidado de papel), se alza con frecuencia la voz del narrador que relata los acontecimientos más signifi-

${ }_{12}$ Me acojo a la distinción que hace Jará y Moreno (Cfr. op. cit., p. 50) sobre personaje esférico y personaje plano. El personaje esférico presenta más de un rasgo caracterizador y se opone al personaje plano, que presenta un solo rasgo dominante. 
cativos de la infancia, el entorno vital, los fallos de educación de Julio -el actante básico- que habrán de incidir en su carácter. Más tarde, Julio, convertido en un joven seminarista, es descrito por el narrador ficto como ser sensitivo e idealista a quien constriñe el ambiente del seminario; esto pone de relieve la vocación literaria del personaje, así como su actitud crítica.

Este mismo procedimiento lo encontramos en una de sus últimas novelas (Lo rojo y lo azul). El narrador hace gala de su omnisciencia presentando el pasado de su héroe, el entorno social en el que se educó, sus dudas y vacilaciones al iniciar una nueva etapa, así como sus defectos y cualidades que se van revelando en su proceso vital.

La opinión del personaje, como elemento caracterizador, se presenta a veces a través de la carta, en la que se revela el carácter, no sólo del emisor, sino también del receptor, al emitir su juicio sobre el mensaje recibido. Así, en la novela Lo rojo y lo azul, Julio recibe una carta de su amigo Arturo que le pone al corriente de su vida y le mueve a la reflexión y análisis de la suya, revelándose su situación anímica y su credo ideológico en el contraste de actitudes:

\footnotetext{
"Julio, sentado en una banqueta, frente al día agonizante, releía una carta de Arturo.

'... y soy feliz porque nunca me falta un duro y una boca de mujer (...).' ¿Cómo es posible llegar a ser feliz? —pensaba Julio-. Seguramente es un tipo de hombre distinto al mío..." (Lo rojo y lo azul, p. 215).
}

Otras veces, la carta ${ }^{13}$ sólo pretende poner de manifiesto la actitud del actante básico, emisor y receptor de su propio mensaje, pues la carta no llega al receptor que la ha motivado; es solamente el desahogo de un espíritu torturado que proporciona al lector el conocimiento de su estado de ánimo.

Adopta, por tanto, una concepción romántica de la esencia de la carta, pues se revela en ella la imagen del que la escribe, la imagen de su autor. Sin embargo, en otros mensajes, la carta presenta a su vez una concepción pragmática. Así, Arturo, cuando tiene que realizar el informe sobre el incendio que ha investigado, se ve obligado a utilizar el código, aséptico e imparcial, impuesto por su profesión. El contenido de la carta o informe lo determina, en este caso, el receptor. La insatisfacción que le produce el sometimiento a este código profesional se observa en las variantes realizadas en sus diversas redacciones, y el mensaje se carga de sugestivas connotaciones; de este modo, se pone de relieve su compleja personalidad: en él confluyen el hombre científico, el poeta y el filósofo.

El diálogo directo es otro de los procedimientos caracterizadores,

13 Sobre las connotaciones que la carta puede tener, resulta imprescindible el estudio de T. Todorov, Literatura y significación, Barcelona, Planeta, 1971, pp. 41 y ss. 


\section{M.a Pilar Martinez Latre}

pues la conversación permite conocer la opinión del actante básico, asi como la de sus interlocutores.

En El convidado de papel, el actante básico dialoga con la maestra, a la que explica la atmósfera familiar en la que crece. En su espontáno diálogo se pone de relieve la ingenuidad del niño. Más tarde, en el seminario, es frecuente encontrar al protagonista y coprotagonista entablando conversaciones. Sus afinidades y diferencias se ponen de manifiesto en estas confidencias nocturnas, con las que burlan la disciplina del seminario. Muy interesante resulta también el diálogo de Julio con Eulalia en el seminario; los reproches de la mujer sobre su actitud evasiva son reveladores juicios críticos que permiten al lector ahondar en la personalidad de Julio. Finalmente, el diálogo de Julio y el sacerdote encargado de la disciplina plasma sus diferentes criterios y personalidades, manifiesta en la actitud irónica y provocadora del alumno ante la escudriñadora mirada del vigilante.

El diálogo tiene también un papel preponderante en la caracterización del actante básico en Lo rojo y lo azul. Julio pone de relieve su credo ideológico, así como la evolución que experimenta su carácter en sus conversaciones con Guillermina, personaje con una concepción de la existencia opuesta a la suya; con Cecilia, la novia que tratará de hacer de él un hombre práctico; con don Braulio, militante socialista y profesor particular de Julio, que le persuadirá de la necesidad de adscribirse en una ideología revolucionaria; con Arturo, avezado soldado veterano, que le ayudará a desenvolverse en la milicia y tratará de frenar sus impulsos revolucionarios, aconsejándole una actitud vitalista y despreocupada.

En la novela Locura y muerte de nadie, el carácter de Arturo, actante básico, se perfilará en los frecuentes diálogos con Juan Sánchez; las confidencias con este hombre suscitan variados consejos y actitudes en Arturo, que se erige en personaje contrastante por su equilibrio y mesura. Muy interesante es el diálogo sostenido por Arturo, entre su consciente y su subconsciente, en una conversación psicoanalítica, en donde el yo, como observa Freud, ${ }^{13}$ se constituye en mediador entre el mundo exterior y el "ello", intentando adaptar el "ello" al mundo exterior. Jarnés cree que todo hombre encierra en su yo un ventrílocuo con el que dialoga en las horas de recapitulación del pasado o de la contrición, y su "ello", su conciencia, dialoga con su yo, en un desdoblamiento de personalidad reflexivo y analítico. Finalmente, el diálogo o conversación de Arturo con la amante, en la culminación de su proceso sentimental, permitirá conocer la evolución experimentada, su desprendimiento o despojamiento del egoísmo que le dominaba, etc...

El monólogo interior ${ }^{14}$ es otro de los procedimientos caracteriza-

${ }_{14}$ El estudio de Freud, El yo el Ello, Madrid, Alianza, Editorial.

15 A. Prieto (Cfr. Morfología de la novela, Barcelona, Planeta, 1975, pp. 32-34) distingue tres tipos de monólogos interiores: el directo, el indirecto y el dirigido. El monólogo interior directo, es la comunicación inconsciente del per- 
dores. De este modo, penetramos en la vida interior del personaje y en sus pensamientos más íntimos. Estos monólogos suelen ser indirectos o dirigidos, de manera que Jarnés trata de poner orden al fluir caótico de la conciencia de su actante, estableciendo una organización lógica en el discurso.

En la novela Lo rojo y lo azul, en la que se presenta el proceso mítico del héroe en busca de su purificación o catarsis, es frecuente encontrar el monólogo interior que permite seguir su evolución psicológica. Su pensamiento íntimo, su crisis de conciencia, se va desvelando a través del monólogo, dirigido unas veces e indirecto, otras.

En La Teoría del Zumbel, el monólogo interior indirecto permite al lector conocer la desazón de la enamorada ante la larga espera del amante, y toda la carga represiva de la líbido, debida a la educación religiosa que se opone a sus impulsos sexuales.

El monólogo interior dirigido alcanza un papel proponderante en las novelas en las que el narrador es el mismo actante básico: Escenas junto a la muerte y El profesor inútil, y la primera parte de Paula y Paulita. En todas ellas, el subjetivismo ${ }^{16}$ jarnesiano, conformador de la estructura general de sus ficciones, se acentúa, y la recurrencia al monólogo interior es mayor.

\section{A.4. LAS CONSTANTES CONFIGURADORAS}

Hay que notar la coincidencia de actitudes, de gustos, de afectos, de concepciones de la existencia, entre los actantes; coincidencias que se convierten en constantes configuradoras. Estas constantes conforman el mundo jarnesiano y sostienen la estructura subjetiva de sus novelas con una marcada tendencia a la proyección autobiográfica. Entre los ras-

sonaje, tal y como fluye su pensamiento, y sin dirigirse a nadie, ni al lector ni a los otros personajes; es, simplemente, la persona que piensa y cuyo pensamiento, con la libertad sintáctica que se quiera, es registrado por alguien que no está. $E l$ monólogo interior indirecto está escrito en tercera persona; aparece "un alguien" que, ordenando sintácticamente, introduce al lector en la mente del personaje; de este modo, con ayuda del autor omnisciente y acercándose al tipo de narración convencional, se convierte en una descripción y expresión del proceso interior de un personaje. Por último, el monólo interior dirigido es un intento de comunicación directa entre la conciencia del personaje y el lector u otros personajes, sin intervención del autor. Ateniéndome a esta clasificación, encuentro en Jarnés una menor recurrencia al monólogo interior directo, síntoma del su cerebralismo y de la actitud de equilibrio que le guía en todo momento.

16 A. Prieto (Cfr. Morfología de la novela, op. cit. p. 32) cree que en la novela moderna de estructura subjetiva el monólogo interior o "corriente de conciencia" alcanza su máxima facultad de manifestarse, su técnica más expresiva para exteriorizar la mayor y más escondida intimidad, encontrado como obra representativa de esta técnica Ulysses, de Joyce. Jarnés conoció esta novela y le dedicó elogiosas críticas, pero no llegó a los extremos y virtuosismo de Joyce, pues su propia concepción de la obra artística se lo impedía. 
gos más significativos de los héroes destacan: la admiración de la mujer, como "resumen de la naturaleza", en cuya contemplación se recrean, contemplación que es un modo de poseerla. El espíritu voluptuoso y sensual que capta las bellezas sensoriales del entorno y se recrea con morosa delectación en los paisajes naturales, libres de toda manipulación. La preocupación por el descubrimiento de la propia identidad, pues solo el conocimiento de nosotros mismos y de lo que nos rodea, según el pensamiento de Jarnés, permite vivir intensamente. La actitud individualista, que surge como réplica o como mecanismo defensivo frente a la atmósfera deshumanizada que se respira en toda sociedad moderna. El rechazo de la vida burguesa en un intento de afirmar la propia personalidad y de alejarse del hombre masa.

Su cosmovisión se va perfilando y alcanza una total coherencia y nitidez en estas constantes. Ya Unamuno, ${ }^{17}$ escritor que se vuelca en sus personajes de ficción, reiterando temas e ideas, sostenía que: "Tiene que ser un pobre el que no se repita a sí mismo a menudo...; un pensamiento es muchas veces original, aunque lo haya expresado uno cien veces. Se le ha ocurrido por un nuevo camino, un nuevo y expreso curso de asociaciones". tivas.

Voy a ejemplificar con alguna de las constantes más representa-

Jarnés, en sus gustos y preferencias, se siente particularmente atraído por la mujer. La atracción por la mujer tiene una importante dimensión en su mundo novelístico. Los actantes básicos se sienten atraídos por la belleza del cuerpo femenino, por "descifrar la incógnita de su fascinante problema plástico". Se recrean en la morosa y voluptuosa descripción de sus formas, y demuestra una especial atracción por los senos femeninos, atracción que llegará a convertirse en una auténtica obsesión freudiana, en opinión de Entrambasaguas. ${ }^{18}$

Julio (El convidado de papel), el Profesor inútil (El Profesor Inútil), el Opositor n. 7 (Escenas junto a la muerte), Saulo (Teoría del Zumbel), Julio (Lo rojo y lo azul), Julio (Paula y Paulita), Arturo (Locura y muerte de nadie), adoptan posturas semejantes ante la presencia de la "hembra hermosa". Julio (El convidado de papel), que ha descubierto la belleza de la mujer siendo casi un niño, al contemplar a Eulalia, la maestra, mientras ésta recibe su baño de sol, se siente atraído especialmente por sus senos:

${ }_{17}$ Unamuno, El Sol, Madrid, recogido en España y los españoles. Cito por Ynduráin (Cfr. Clásicos modernos. Estudios de crítica literaria, Madrid, Prensa Española, p. 40). El Dr. Ynduráin cree que las reiteraciones en Unamuno se deben a su espíritu de predicador laico que trataba siempre de impresionar a los oyentes y lectores.

18 Entrambasaguas (Cfr. Las mejores novelas contemporáneas, ed. cit., p. 1.346).. No obstante, hay que señalar que la belleza de los senos femeninos y su exaltación se da en escritores muy próximos a los Nova Novarum, que ejercieron en ellos una marcada influencia. Un claro ejemplo lo constituye Gómez de la Serna con su miscelánea, significativamente titulada, Los Senos. 


\section{La Novela JaRnestana y SUS PERSONAJES DE fiCcion}

"Eulalia contempla a Julio (...), hace un gesto para besarle. Con el movimiento brinca un seno, revoltoso, jovial..." (p. 33).

Pero no es sólo esta parte femenina la que más le atrae en sus primeros contactos:

"Le gusta más el hombro de todo aquel paisaje entornado (...), perfección que supera la tersura de las flores: de tal suavidad que nunca podrían las frutas y flores luchar con él" (Ibíd., p. 33).

"Senos los ve Julio en cualquier parte. Julio ha visto los de todas las mozas del pueblo: (...) Julio ha visto senos duros, cobardes, tímidos, infantiles, altaneros, cínicos, maduros, tersos, vacíos, opulentos..." (Ibid., pp. 33-34).

Porque el niño tiene una experiencia habitual de los senos femeninos, ha preferido acariciar el hombro desnudo, aunque Jarnés evidencia su complacencia voluptuosa en esa adjetivación variadísima con que los matiza.

Dentro del seminario, Julio vive inmerso en una realidad literaria y evasiva, en donde la mujer se hace presente con sus atractivas formas cargadas de sensualismo estético. Si Dalí ${ }^{19}$ logra que, en la sombra y oscuridad, su imaginación fantástica modifique a voluntad los contornos de la mujer, el héroe jarnesiano consigue que las volutas de humo que ascienden de su frugal comida adopten las voluptuosas formas del cuerpo femenino:

"Julio (...) frente a la materia más humilde se siente impetuoso Pigmalión. Porque el humo gris se eleva, se alarga partiéndose en dos cilindros que lentamente se van torneando hasta fijar el contorno de las piernas de Lucía. Se juntan luego las columnas de humo para redondearse en una voluptuosa esfera (...) que se alargaba hacia arriba hasta bifurcarse de nuevo en otros dos cilindros más finos (...). El rostro se lo ocultan siempre los senos henchidos retadores, con sus puntas de carmín..." (Ibíd., p. 206).

La dimensión estético-erótica, ${ }^{20}$ una de las claves de su novelística, aparece también en El profesor inútil. El sensitivo profesor contempla entusiasmado a la Maja desnuda de Goya. La belleza de sus senos le

19 Jarnés transforma la realidad a través de un procedimiento surrealista, del cual es Dalí un egregio cultivador: la "paranoia crítica". Sobre este procedimiento habla Paul Ilie en Los surrealistas españoles, traducción de J. C. Curutchet, Madrid, Taurus, 1972.

${ }^{20}$ V. Fuentes (Cfr. "La dimensión estético-erótica en la novela jarnesiana", Madrid, Cuadernos Hispano-Americanos, 1969 , n. ${ }^{\circ} 235$, p. 25), interpreta la creación jarnesiana desde la dimensión estético-erótica, dentro de la cual cree que su obra alcanza su plenitud de significado, y, así, dice:

"Sobre la acción liberadora de la estética y el erotismo basa Jarnés su concepción de la existencia". 


\title{
M. ${ }^{a}$ Pilar Martinez Latre
}

subyuga y le mueve a una original interpretación en la que cada uno de los senos representa dos personalidades diferentes, o, lo que es lo mismo, dos planos de la realidad: la realidad vital y la realidad artística:

\begin{abstract}
"Vea usted, Ruth, con qué desparpajo nos mira el seno izquierdo. Tiene toda la valentía y el garbo de las majas. Es el verdadero seno de la maja. Vea cómo nos invita a comprobar su dureza geométrica y su caliente y superfemenina suavidad. Su poesía y su realidad (...). Y este otro seno que parece huir de nosotros, que prefiere desafiarnos (...) con su perfil completo, al mismo tiempo henchido y apretado, exactitud y exuberancia, como debe ser el arte (Profesor Inútil, pp. 95 y 96).
\end{abstract}

La atracción que la mujer ejerce es imposible de esquivar. El Profesor inútil lo intenta sin resultado, imaginándose el esqueleto femenino. En su intento, la visión coincide con la estética de vanguardia expresionista, tan próxima al estilo pictórico barroco, macabro y nihilista. El horror que esta visión le produce le mueve a la plasmación cubista ${ }^{21}$ del cuerpo femenino. Pero la fría imagen, en la que se ha convertido la sensual discípula, dura sólo unos breves instantes: la "pura geometría" se transforma de nuevo en forma voluptuosa.

En el variado itinerario sentimental del sensitivo y vanguardista Profesor inútil, una nueva mujer despierta su instinto de Eros hacia la belleza carnal. El seno femenino sigue siendo el polarizador de todas las miradas, y el instigador del deseo:

“(...) confieso humildemente que no contemplé el seno izquierdo como eje de ninguna estructura, sino como relieve de carne donde ensayar caricias" (Ibíd., p. 184).

Para paliar esta sensación táctil que toda contemplación próxima produce, Jarnés - siguiendo fielmente a Ortega y su teoría del punto de vista_ 22 cree en la necesidad de alejarse, pues sólo desde la lejanía el artista se convierte en creador y la mujer en objeto contemplado como obra de arte.

El Opositor n. 7 se comporta también como enamorado de la mujer, subyugado por su belleza, en cuya contemplación se detiene morosamente, con delectación voluptuosa:

${ }^{21}$ "Ya tengo de nuevo a mi discípula vestida de su piel (...). A las fórmulas ascéticas prefiero las fórmulas cubistas (...); rápidamente los brazos de Carlota se truecan en cilindros; los senos en pequeñas pirámides, mejor que en casquetes esféricos de curva peligrosa; los muslos, en troncos de cono invertidos" (Ibíd., p. 148).

${ }^{22}$ El punto de vista jarnesiano se basa, con frecuencia, en la perspectiva orteguiana. Ortega propugna la necesidad de distanciarse, alejándose del objeto de contemplación y despojándose de toda relación afectiva, pues sólo así el artista se convierte en un dios creador capaz de realizar una obra perfecta; esta opinión se recoge en "Unas gotas de fenomenología", en la obra La deshumanización del arte, obra completa, Madrid, Revista de Occidente, 1967, vol III, p. 353 y ss. 


\title{
La Novela Jarnesiana y sus personajes de ficcion
}

\begin{abstract}
"Otra vez se le desnuda el hombro. Ahora es el izquierdo. Hay cierto pugilato entre los dos. Me complace ver esos centímetros más de piel tersa, redonda. Me deleita seguir esas curvas que nacen en el lóbulo de la oreja (...). No puedo seguir las del seno, y me contento con perseguir las de los brazos" (Escenas junto a la muerte, p. 29; el subrayado es mío).
\end{abstract}

El joven erótico Saulo (Teoría del Zumbel), epíteto que acompaña su caracterización, con una ganada reputación de mujeriego, muestra siempre una predilección por los senos, pues sus formas revelan "la perfección y juventud de la carne de la hembra".

También Arturo (Locura y muerte de nadie) inicia la posesión de la mujer, su amante, previa contemplación de su cuerpo desnudo:

"Curvada, junto a una silla, construye el arco del placer. Su cuerpo es una rama en tensión de la que cuelgan dos menudos conos, tan sabrosos" (Locura $y$ muerte de nadie, p. 1.418).

La mujer se convierte para el héroe de Paula y Paulita en el "nuevo eje de perspectiva" que impregna el paisaje de armonía y sensualismo voluptuoso despojado de artificios mercantiles.

Finalmente, Julio (Lo rojo y lo azul) muestra su entusiasmo y admiración por la mujer, entusiasmo que se debilita cuando le rodea la miseria. Es como si la belleza femenina se contagiara de su sordidez, y no pudiera lucir todo su esplendor al faltarle el marco adecuado.

Así pues, la voluptuosidad, para los héroes jarnesianos, se convierte en una forma de vivir intensamente, una manera de aprehender la realidad, que se opone en todo momento al "sentimiento turístico de la vida", como observa Zuleta. La mujer en el mundo jarnesiano se erige en resumen de la naturaleza, en su obra más perfecta.

Los convencionalismos sociales. Ante esta visión de la sociedad, no es raro que el héroe se refugie en su individualismo y haga patente su rechazo a los convencionalismos sociales. Jarnés deja entrever, en ese amor por sus héroes, la preocupación orteguiana por el hombre y su despreocupación por la humanidad.

Los actantes básicos adoptan, a lo largo de su trayectoria vital, un rechazo consciente, cuando no una ridiculización, de la vida burguesa, que supone una pérdida de la personalidad, al generalizarse un tipo de comportamiento, de costumbres, de ideas o deseos, que "arrolla todo lo diferente, egregio, individual, cualificado y selecto".

Desde las primeras novelas, el actante básico postula la vida libre de convencionalismos. El joven seminarista Julio (El convidado de papel) imagina una escena intima de cuatro familias burguesas, y ridiculiza su comportamiento:

"Es la hora en que aparecen sobre la mesa de todos los comedorcillos burgueses el mismo plato de lechuga (...). El burócrata lírico, con otros tres compañeros, se sentará ahora a la mesa, una sobre otro, al mismo costado, frente a la mujercita. Sólo discreparán los cuadros en el número de niños. El resto es idéntico (...). Cuando el esposo del tercero escancia su vino en el 


\title{
M. ${ }^{a}$ Pilar Martinez Latre
}

vaso, los esposos del segundo, primero y principal empuñan también la botella. Las cuatro mujercitas parten a su tiempo la carne y regañan al niño..." (El Convidado de papel, p. 147).

No hay nada que les diferencie en su cotidiano vivir, y hasta el amor se convierte en esta sociedad burguesa en una rutina mecánica:

\begin{abstract}
"Ve iluminarse las cuatro alcobas, caer cuatro batas, adoptar cuatro mujeres la misma deliciosa postura para desenfundar sus piernas (...). A los cuatro minutos, cuatro máquinas procreadoras, una sobre otra, comienzan a funcionar tan rítmicamente, que no es posible contener la risa" (Ibíd., p. 148).
\end{abstract}

La escena se convierte en una parodia burlesca. Los hombres aceptan esta rutina. $\mathrm{Su}$ vida monótona, su falta de originalidad, produce la risa de Julio, espíritu evasivo y fantástico. La crítica a los convencionales matrimonios de la burguesía es constante. El Profesor inútil, enamorado de toda hembra hermosa, se muestra irónico y desenfadado ante la actitud de su amante que pretende dar a sus amores un cauce legal. Para el héroe, el amor tiene que vivir libre de toda atadura, y ante el proyecto de matrimonio de la mujer, se desmorona la aventura amorosa. El profesor pierde todo entusiasmo:

"Me hiere vivamente la mirada de Carlota, que quiere leer en mí el epílogo... Yo enriquecería la aventura con otro dulce episodio; pero Carlota pretende reeditarla corrigiendo bien las erratas (...). Ella querría hacerme recorrer el largo camino del amor burgués para adquirir lo que ya pudo lograrse por el camino del instinto" (El Profesor Inútil, p. 164).

En estas relaciones sentimentales hay instantes amorosos, momentos fugaces de placer. Difícilmente triunfa el amor total, pues, unas veces, lo hace imposible el ansia de libertad y, otras, el amor panteísta que los guía y los convierte en insaciables soñadores, enamorados de toda hembra hermosa.

\section{B. ANALISIS FUNCIONAL DE LOS PERSONAJES}

El personaje no es solamente una esencia psicológica, como observan los estructuralistas, sino un "participante". De acuerdo con esta perspectiva, es preciso completar la visión del personaje como participante en una serie de acciones dentro del mundo ficto. Sin embargo, como señala acertadamente B. Barthes, la "dificultad planteada por la clasificación de los personajes es la ubicación (y, por tanto la existencia) del sujeto en toda matriz actancial, cualquiera que sea su fórmula";23 de aquí que este análisis no se someta a una matriz determinada, si bien la misma inmanencia del relato, dada su estructura subjetiva, me obliga a ceñirme al

${ }^{23}$ R. Barttes, "Introducción al análisis estructural de los relatos", en Análisis estructural del relato, Buenos Aires, Editorial Tiempo Contemporáneo, 1970. 
sujeto protagonista, al que considero como actante básico. Me centra ré en su funcionalidad y en la participación de los personajes secundarios y anecdóticos ${ }^{24}$ en su relación con dicho actante.

El actante básico de la novela jarnesiana es el eje o centro de la acción, comportándose unas veces como sujeto agente $\mathrm{y}$, otras, como sujeto paciente. Como sujeto agente, actúa como incitador, modificador y protector, impulsado por móviles hedonistas en su dimensión estéticoerótica. Su actuación queda contrarrestada por su carácter pasivo, adinámico, que se manifiesta en sus vacilaciones antes de iniciar acción alguna. Se muestra frenado por su actitud introspectiva y subjetiva, así como por su entusiasmo por la psicología de la percepción para llegar al conocimiento del mundo circundante: naturaleza y hombre.

En su actuación como sujeto paciente, recibe influencias subjetivas, especialmente de aquellos personajes que muestran ciertas afinidades o paralelismos con él, y que actúan como agentes beneficiarios, ayudando a su proceso de anagnórisis. En definitiva, el actante básico es el centro de la ficción, y los demás personajes, aun aquellos que puedan considerarse coprotagonistas, permanecen subordinados a él.

Entre los personajes anecdóticos o incidentales, las funciones primordiales son: la ambientadora (la pareja de la guardia civil, el guía, el jardinero en Paula y Paulita; el soldado, el cabo, el capitán en Lo rojo y lo azul. La de crítica social mediante personajes-tipo que permiten al actante mostrar su concepción de la vida, su mundo de valores (los seminaristas - Manolo, Plá-, los sacerdotes - Fauno, Dr. Ropon, Monsieur-, en El convidado de papel; los camareros, Casanova, el guía, en Paula y Paulita; el borracho, el funcionario de la casa de socorro, el presunto ladrón, el vagabundo, en Escena junto a la muerte. La función mítica, reproduciendo un comportamiento mítico que conforma la trama (Susana como Juno, Isabel como Afrodita, Aurora como Minerva, en Escenas junto a la muerte; Juan y Ceferino como Hyacinthos y Cyparissos, Herminia como Walkiria, en El profesor inútil; Eulalia como Dánae en El convidado de papel. La función coadyuvante en el desarrollo de la trama, proporcionando indicios, o informando, retrasando el proceso del héroe, aconsejando, etc. (El librero, la prostituta, el cartero, el acomodador en Locura y muerte de nadie, el teniente, el cabo Ramírez, Rubí en Lo rojo y lo azul, las prostitutas Carmen, Estrella, Lola, el conserje, la tiple, la secretaria en Teoría del Zumbel.

Para llegar a esta síntesis ha sido necesario seguir la actuación de cada personaje en su propio mundo de ficción. De este estudio analítico doy muestra con las novelas Locura y muerte de nadie y Lo rojo y lo azul.

En la novela Locura y muerte de nadie, Arturo se revela como actante básico, destacando nítidamente del resto de los personajes, al funcionar como integrador de todos los acontecimientos. Como él se inicia y

24 Terminología de Jará y Moreno, Anatomía de la novela, ed. cit. p. 54. 
se cierra el relato, siendo el centro o eje en torno al cual se va a subordinar el comportamiento de los demás personajes fictos.

En su actuación como sujeto agente, es el confidente de la problemática personal de Juan Sánchez, el testigo de sus reiterados fracasos cuando trata de afirmar su personalidad; es el consejero y protector en el Banco cuando descubre su pecho para mostrar esa firma que le permite identificarse; en el atentado callejero, cuando trata desaforadamente de destacarse y ser captado por la cámara, apareciendo como figura guiñolesca y esperpéntica (esta escena filmada será más tarde contemplada por el propio Juan Sánchez, en compañía de su mujer y de Arturo, que tratará de paliar la tristeza y decepción que produce en este hombre la contemplación de sí mismo); le acompañará en la visita a sus antepasados, en donde descubrirá la mediocridad de su origen, y al cabaret, en el cual será confundido con otro hombre por una vulgar "cocotte". En su intento de revelarse como héroe a través de la oratoria, es Arturo el que, sin querer, ocupa su lugar; e, igualmente, el desfalco urdido para darse a conocer a los demás, se adjudicará exclusivamente a su socio, fracasando una vez más en su intento. En su actuación como consejero beneficiario, Arturo intenta que abandone sus proyectos de suicidio, instándole a iniciar una nueva vida. Es también Arturo el que coadyuva indirectamente a su final anodino, pues, cuando va a poner en práctica sus sugerencias y abandona la ciudad, es arrollado por un taxi, convirtiéndose en un número más de la fría estadística con la que el hombre entrega gratuitamente su vida en aras del progreso.

Juan Sánchez es también víctima degradada de las relaciones sentimentales de las que serán sujetos agentes su esposa y su confidente Arturo, pues, cuando comienza a sospechar, no logra descubrir ninguna prueba que le permita erigirse en marido ofendido, experimentando una nueva frustración y quedando a los ojos del lector como un pobre hombre, ridículo y egoista, al que hasta los seres más queridos le son infieles.

Arturo, no sólo va a ser el hombre razonador y pragmático que actúa como testigo-consejero, sino que como hombre sentimental que es, vive una experiencia amorosa dinámica y evolutiva, que afecta a su carácter, y a la que coadyuvan varios personajes secundarios.

En sus relaciones se comporta como sujeto agente frustrador, porque sólo busca en la mujer el placer físico, la somete a su egoísmo y se niega a conocer su problemática humana. La presencia del rival, Alfredo, socio de Juan Sánchez, y presunto amante de Matilde, ejerce una influencia en sus sentimientos, despertando los celos y la desconfianza ante la mujer, moviéndole a terminar su relación. Pero, más tarde, acepta la influencia benéfica de unos parientes, Braulio y su madre, consejeros objetivos, que actúan como agentes modificadores, revelándole la grandeza de espíritu de su amante, que se somete como una sumisa esclava a las extravagancias y egoísmos de su esposo Juan Sánchez. El viaje y el contacto con estas persouas mueven a la reflexión a Arturo, y comienza a conocer en profundidad a la mujer, y, por tanto, a amarla. El viaje le ha dado una nueva perspectiva, al poder contemplar la realidad 


\section{La Novela JARnesiana y SUS PERSONAJES DE FICCION}

humana de una forma más distanciadora, y, por tanto, más objetiva.

En esta variada gradación de su proceso sentimental, existen una serie de personajes incidentales con una presencia ocasional, que actúan en función de la trama y que no sólo proporcionan nuevos datos, sino que se comportan como agentes informadores protectores o frustradores; así ocurre con el acomodador del cine, el cartero, la prostituta, el librero, etc. El acomodador actuará como agente informador objetivo, poniendo en conocimiento del lector el comienzo de las relaciones de los amantes así como su evolución y el momento de tibieza por el que atraviesan al volver tras un lapso de tiempo al cine. El cartero actuará como agente relacionador al traer a Arturo una carta de Matilde, que le expone su estado de ánimo y le suplica asista a una cita para reconciliarse. El librero será un frustrador que le proporcionará a Arturo nuevos indicios que le reafirmen en la infidelidad de la amada, al venderle un libro perdido por Matilde en una casa de citas. La prostituta se comportará como agente protector, que ayudará con su banal conversación a Arturo a soportar la espera tensa y angustiosa de la amante.

Pero quizás en los mismos agentes frustradores hay, en definitiva, una acción benéfica, pues permite a Arturo salir del tedio en el que se desenvolvían sus relaciones y volver a recuperar su entusiasmo, hasta llegar a la plenitud del amor, poco frecuente en los héroes jarnesianos.

Como filósofo, Arturo actuará como un personaje analítico, que tratará de llegar al conocimiento de la realidad exterior e interior desde una perspectiva orteguiana, siendo fiel exponente de la ideología del escritor, presentando su teoría sobre las nuevas corrientes o directrices de la sociedad y su incidencia en el arte; novela, poesía, etc.

Arturo será, finalmente, el hombre equilibrado (artista, filósofo, científico, que propugna Jarnés) que se erige en el héroe individualista, que se aleja de los acontecimientos y renuncia a su amor por Matilde, adoptando la postura de un ser superior que supervisa o da su aquiescencia a los derroteros que van a seguir los demás personajes de la ficción.

En la novela Lo rojo y lo azul, Julio es el actante básico, que actúa como un héroe mítico, iniciándose en una nueva aventura vital a la que contribuyen los demás personajes del relato. Es el eje de la trama, de la estructura, y portavoz de la tesis novelística. En su proceso de iniciación, recibe primero la ayuda del avezado soldado veterano que actúa como su maestro en la nueva vida militar que comienza. Es un consejero amigo que le estimula para vivir libremente, gozando con los placeres que la vida le proporciona, sin someterse a ninguna ideología. Pero estos móviles hedonistas, con los que tan bien se aviene el carácter de Julio, serán depuestos al recibir el influjo de Cecilia que actuará como agente modificador de su proceso vital. Cecilia, como la hechicera Circe, subyugará con su belleza al nuevo Ulises, y le obligará a labrarse un porvenir, sometiéndolo a los convencionalismos burgueses.

Liberado del influjo de Cecilia, se iniciará en una nueva etapa en la que don Braulio, un entusiasta socialista, actuará de nuevo como consejero intentando hacer de Julio un militante. Pero el agente desperta- 


\section{M.a Pilar Martinez Latre}

dor que ejercerá una auténtica influencia en Julio y que le moverá a adscribirse al socialismo y a participar en una conspiración, será un rico tendero, personaje incidental, que despierta en Julio, al tratarlo vejatoriamente, la necesidad de la revancha.

Julio actuará desde este momento como agente modificador, intentando inocular en los soldados el virus revolucionario, abandonando a la joven Rubí, que le ofrecía un amor desprendido, para el que no tiene tiempo, una vez hecha su opción política. El soldado de guardia será su primer discípulo, sujeto paciente involuntario que, ante el panfleto subversivo puesto en sus manos por Julio, se inhibirá completamente.

Una serie de personajes secundarios contribuyen también con su actuación al desarrollo del proceso vital de Julio. Así, Guillermina, personaje contrastante, por cuanto le mueven unos planteamientos materialistas que se oponen a la actitud desprendida y vitalista del héroe, sirve de personaje ejemplificador que le ratifica en su postura, pues su programación del futuro le ha conducido al fracaso, mientras que Julio, sin ninguna programación, ha conseguido una estable relación que le augura un cómodo porvenir. Pero Guillermina es también el personaje que viene a reforzar el mensaje novelístico, que está al servicio de la ideología jarnesiana, y su opción socialista será hecha para vengarse de sus fracasos. Julio y Guillermina, personajes contrastantes, adoptan, sin embargo, posturas afines. Pero la mujer sigue hasta el final en su deseo de venganza, y actúa como agente influenciador de Julio que, llegado el momento, se siente incapaz de participar en la sublevación, prevaleciendo sus móviles hedonistas y su actitud vital. En la crisis que desencadena su negativa de participación en la sublevación, recibe la ayuda del teniente, que actúa como agente protector y le ayuda a salir de la confusión, suscribiendo la tesis jarnesiana, en la que sólo el hombre incapaz de "gozar de una libre e intensa vida, se encadena odiando".

En el proceso vital de Julio, existe un cierto paralelismo con la conversión de Don Quijote, estudiada por Rosales. ${ }^{25}$ El héroe jarnesiano, como el cervantino, busca en la conversión el fundamento de su vida y todo ello entraña la ruptura con el pasado, la elección absoluta de sí mismo, la aceptación del fracaso inherente a la existencia humana, y la renovación de la esperanza original.

Otros personajes, como el cabo Ramírez, o el socialista Pepe Cuevas, forman parte del grupo de conjurados y sirven para disminuir el entusiasmo de Julio al mantener unos planteamientos chauvinistas que repudia. Están, por lo tanto, en función del mensaje novelístico y ejercen, a su vez, una influencia inhibidora en Julio.

Finalmente, una serie de personajes como "el cabo", el soldado, el capitán", son meros personajes ambientales que conforman la atmósfera militar en la que se mueve nuestro héroe y que sirven para retardar,

25 L. Rosales, Cervantes y la libertad, Madrid, sociedad de estudios y publicaciones, 1960. 
con su breve presencia y su circunstancial experiencia vital, el desarrollo de los acontecimientos.

Todos los personajes del relato inciden objetiva o subjetivamente en la aventura mítica de este héroe jarnesiano, como incitadores, despertadores, consejeros, inhibidores, etc.

El estudio analítico y funcional de los personajes jarnesianos permiten conocer la riqueza y coherencia de su mundo de ficción, mundo que lo conforman otros importantes elementos tales como: la estructura a sintaxis del relato novelesco, la perspectiva o punto de vista, el espacio y el tiempo, etc... Todos ellos en estrecha relación con el mensaje novelístico y su significado, pero que escapan a las posibilidades de este trabajo.

Jarnés es un novelista injustamente olvidado como lo fue la generación de novelistas en las que se halla adscrito: LOS NOVA NOVARUM Su obra marcó nuevas direcciones a la novela con sus innovaciones estéticas y técnicas, reavivadas por la trayectoria neobarroca de la actual novela española e hispano-americana. 
